\title{
Microarray analysis of MicroRNA expression in peripheral blood mononuclear cells of critically ill patients with influenza A (H1N1)
}

Hao Song ${ }^{1,2,3 \dagger}$, Qi Wang ${ }^{2,3 \dagger}$, Yang Guo ${ }^{4 \dagger}$, Shunai Liu ${ }^{2,3}$, Rui Song ${ }^{5}$, Xuesong Gao ${ }^{2,3}$, Li Dai ${ }^{4}$, Baoshun Li ${ }^{5}$, Deli Zhang ${ }^{1,2^{*}}$ and Jun Cheng ${ }^{2,3^{*}}$

\footnotetext{
Abstract

Background: With concerns about the disastrous health and economic consequences caused by the influenza pandemic, comprehensively understanding the global host response to influenza virus infection is urgent. The role of microRNA (miRNA) has recently been highlighted in pathogen-host interactions. However, the precise role of miRNAs in the pathogenesis of influenza virus infection in humans, especially in critically ill patients is still unclear.

Methods: We identified cellular miRNAs involved in the host response to influenza virus infection by performing comprehensive miRNA profiling in peripheral blood mononuclear cells (PBMCs) from critically ill patients with swine-origin influenza pandemic H1N1 (2009) virus infection via miRNA microarray and quantitative reversetranscription polymerase chain reaction (qRT-PCR) assays. Receiver operator characteristic (ROC) curve analysis was conducted and area under the ROC curve (AUC) was calculated to evaluate the diagnostic accuracy of severe H1N1 influenza virus infection. Furthermore, an integrative network of miRNA-mediated host-influenza virus protein interactions was constructed by integrating the predicted and validated miRNA-gene interaction data with influenza virus and host-protein-protein interaction information using Cytoscape software. Moreover, several hub genes in the network were selected and validated by qRT-PCR.

(Continued on next page)
}

\footnotetext{
*Correspondence: zhangdeli@tsinghua.org.cn; jun.cheng.ditan@gmail.com

'Equal contributors

'MOA Key Laboratory of Animal Biotechnology of National Ministry of

Agriculture, Institute of Veterinary Immunology, and Research Laboratory of Virology, Immunology \& Bioinformatics, Division of Veterinary Microbiology \& Virology, Department of Preventive Veterinary Medicine, College of Veterinary Medicine, Northwest A \& F University, Yangling, 712100, Xi'an City, Shaanxi Province, China

${ }^{2}$ Institute of Infectious Diseases, Beijing Ditan Hospital, Capital Medical University, Beijing 100015, China

Full list of author information is available at the end of the article
} 
(Continued from previous page)

Results: Forty-one significantly differentially expressed miRNAs were found by miRNA microarray; nine were selected and validated by qRT-PCR. QRT-PCR assay and ROC curve analyses revealed that miR-31, miR-29a and miR148a all had significant potential diagnostic value for critically ill patients infected with H1N1 influenza virus, which yielded AUC of $0.9510,0.8951$ and 0.8811 , respectively. We subsequently constructed an integrative network of miRNA-mediated host-influenza virus protein interactions, wherein we found that miRNAs are involved in regulating important pathways, such as mitogen-activated protein kinase signaling pathway, epidermal growth factor receptor signaling pathway, and Toll-like receptor signaling pathway, during influenza virus infection. Some of differentially expressed miRNAs via in silico analysis targeted mRNAs of several key genes in these pathways. The mRNA expression level of tumor protein T53 and transforming growth factor beta receptor 1 were found significantly reduced in critically ill patients, whereas the expression of Janus kinase 2, caspase 3 apoptosis-related cysteine peptidase, interleukin 10, and myxovirus resistance 1 were extremely increased in critically ill patients.

Conclusions: Our data suggest that the dysregulation of miRNAs in the PBMCs of H1N1 critically ill patients can regulate a number of key genes in the major signaling pathways associated with influenza virus infection. These differentially expressed miRNAs could be potential therapeutic targets or biomarkers for severe influenza virus infection.

Keywords: Critically ill patient, 2009 H1N1 Influenza pandemic, miRNA, Host pathogen interaction, Systems biology

\section{Background}

In 2009, human infection with novel swine-origin influenza A (H1N1) virus became a health burden throughout the world. The H1N1 virus spread rapidly to countries worldwide, leading the World Health Organization (WHO) to declare on 11 June 2009 the first influenza pandemic in more than 40 years [1].

Like other viruses, influenza virus relies on host cellular processes throughout its replication cycle. Various strategies have been used to characterize host factors involved in influenza virus infection to better understand the molecular mechanisms of viral pathogenesis. These strategies include yeast two-hybrid analysis [2], genomewide RNA interference (RNAi) screen [3-5], and integrative analysis combining several different approaches [6,7]. Hundreds of host proteins have been identified and a physical, regulatory, and functional map of hostinfluenza interactions has been drawn, which shows the global perspective of virus infection and uncovers the complex host-pathogen relationships. However, the concrete mechanism is still unclear; more studies relevant to influenza virus are still needed.

MicroRNAs (miRNAs) are small ( 22 nucleotides long), single-stranded non-coding RNAs that mediate posttranscriptional silencing of target genes. In animals, miRNAs usually bind to complementary sites in the $3^{\prime}$ untranslated region (UTR) of specific target genes, resulting in inhibited protein expression and induced target mRNA degradation [8]. MiRNAs have emerged as key regulators of diverse biological processes, including development [9], cancer [10], immune response [8,11] and so on. Special miRNAs have been reported to participate in regulating cross-talk between the host and the pathogen in viral infections and have a major function in viral pathogenesis [12-14]. For influenza virus, differential expression of cellular miRNAs have been found both in avian influenza virus-infected chickens $[15,16]$ and reconstructed 1918 influenza virus [17] or the highly pathogenic avian influenza H5N1 virus [18] infected mice. Several cellular miRNAs, such as miR-323, miR491, miR-654, and Let-7c have recently been reported to inhibit H1N1 influenza A virus replication by downregulating the viral gene expression in infected MDCK or A549 cells $[19,20]$. In addition, temporal- and strain-specific host miRNA molecular signatures have been demonstrated in human A549 cells infected with swine-origin influenza pandemic H1N1 (2009) and highly pathogenic avian-origin influenza H7N7 (2003) [21]. However, it is still unclear whether miRNAs also play an important role in human being infected with influenza virus, especially critically ill patients caused by influenza virus infection.

Human peripheral blood mononuclear cells (PBMCs) provide an important source for clinical diagnosis and pathogenesis discovery. In contrast to target tissue biopsy, blood is not limited by restricted access to target tissues. Blood is a highly dynamic environment, which is another advantage. Blood has been proposed as a 'sentinel tissue' that reflects disease progression in the body [22]. The leukocytes can interact and communicate with practically every tissue so that these cells have rich information regarding inflammation and immune responses. Gene expression profiling in peripheral blood has been used to describe the pathogenesis of infectious diseases, including influenza, and to discover unique signatures of disease or to identify novel drug targets for treatment [22-33]. Influenza A virus can infect and replicate in human primary dendritic cell (DC), macrophages, and 
natural killer cells [34-36]. Therefore, it is appropriate to use PBMC for gene expression profiling, and it holds great promise for clinical diagnosis and research [22].

Although multiple signaling pathways and various cellular factors have been associated with influenza virus infection, the function of the miRNAs of PBMCs is still poorly understood. In the current study, we used both miRNA microarray and quantitative reversetranscription polymerase chain reactions (qRT-PCR)based approaches to assess miRNA expression in PBMCs from the critically ill patients with H1N1 infection, and found some differentially expressed miRNAs that can be highly related to influenza virus infection. We subsequently constructed a direct gene interaction network to illustrate the interaction mechanism of these miRNA targets with each other via protein-protein interaction during influenza virus infection. This network revealed potential important functions that miRNAs have in host and pathogen interactions, and provided several directions for further study. We then validated several hub genes in the network using the qRT-PCR method and demonstrated that the hub genes, which are highly important during influenza virus infection, can be modulated by multiple miRNAs.

\section{Methods}

\section{Ethics statement}

This study was approved by the Beijing Ditan Hospital Ethics Committees, and informed consent was obtained from subjects involved at the time of sample collection. All volunteers provided written informed consent for sample collection and subsequent analysis.

\section{Patients and control individuals}

From September 2009 to November 2009, a total of 299 confirmed cases of human infection with the novel strain H1N1 were admitted to the intensive care unit (ICU) of Beijing Ditan Hospital in China. We classified the patients according to the case definition developed by the Ministry of Health of China. The symptoms in severely ill patients included: (1) sustained high fever over $3 \mathrm{~d}$; (2) violent cough with purulent sputum or blood in sputum and chest pain; (3) increased respiratory frequency, dyspnea, and cyanosis; (4) altered mental status, such as unresponsiveness, lethargy, restlessness, or seizures; (5) severe vomiting or diarrhea with dehydration; (6) signs of pneumonia in chest X-ray or computerized tomography scan; (7) rapid increase in cardiac enzymes including creatine kinase $(\mathrm{CK})$ or creatine kinase isoenzyme (CK-MB), and (8) aggravation of basic illness.

Critical cases were defined when one of the following conditions occurred: (1) respiratory failure; (2) septic shock caused by severe infection; (3) multiple organ dysfunction syndrome, or (4) requirement of intensive care
[37]. The diagnoses were confirmed using the specific RT-PCR protocol developed by the Center for Prevention and Disease Control in Atlanta, Georgia, USA, and recommended by WHO for Human Influenza A/H1N1/ 2009 [38]. Thirteen healthy donors with no recent illness or treatment for a chronic medical condition and diagnosed as negative to influenza $\mathrm{A} / \mathrm{H} 1 \mathrm{~N} 1$ using the specific RT-PCR protocol were included as control group.

\section{RNA isolation and quality control}

Blood samples were collected in EDTA-treated tubes as soon as the patients were admitted to the ICU. PBMCs were isolated by standard Ficoll density gradient centrifugation and stored in RNAlater (Ambion) at $-80^{\circ} \mathrm{C}$ before RNA isolation.

Total RNA was isolated using the mirVana miRNA PARIS kit (Ambion), according to the protocol of the manufacturer. RNA concentration and RNA integrity were determined by capillary electrophoresis on an Agilent 2100 Bioanalyzer (Agilent Technologies); only the samples with RNA integrity number $>7$ were used. RNA samples were stored at $-80^{\circ} \mathrm{C}$ until further processing.

\section{MiRNA expression profiling}

The Agilent human miRNA microarrays (version 3.0, based on Sanger miRBase version 13.0) [39] were used to compare the expression profiles of critically ill patients $(n=5)$ and healthy controls $(n=3)$. The samples used for miRNA expression profiling were randomly selected from the two groups. Total RNA (100 ng) from each sample was used as inputs for labeling via Cy3 incorporation. After hybridization and washing, microarray slides were scanned with Aligent Microarray Scanner (Agilent, Santa Clara, CA, USA). Scans were performed at $5 \mu \mathrm{m}$ resolution and dye channel was set to green (PMT100, PMT5). Labeling and hybridization were performed at the Shanghai Biochip Company, according to the protocols in the Agilent miRNA microarray system. Microarray images were analyzed with Feature Extraction Software (Agilent, Santa Clara, CA, USA). The signal after background subtraction was exported directly into the GeneSpring GX10 software (Agilent Technologies, Santa Clara, CA) for quantile normalization. The mean normalized signal from biological replicates was used for comparative expression analysis. For the filtering step, the features (miRNA) whose percentage of detection is $100 \%$, under at least one experimental condition, are retained for further analysis. Significance analysis of Microarrays [40] software was used to determine differentially expressed miRNAs between patient and control groups. Gene Cluster 3.0 [41] and Java TreeView software [42] were used to 
perform differentially expressd miRNA hierarchical cluster analysis and visualization.

\section{Microarray data submission}

The microarray data submission for human arrays is MIAME compliant. The raw and normalized microRNA data have been deposited in NCBI's Gene Expression Omnibus (GEO) database [43] and are accessible through GEO Series accession number GSE24956.

\section{QRT-PCR}

QRT-PCR of microRNAs was performed using Taqman miRNA assays (Applied Biosystems, Foster City, California), according to the instructions of the manufacturer, with the 7500 real-time PCR system (Applied Biosystems, Foster City). The assays were performed for nine miRNAs (hasmiR-146b-5p, has-miR-148a, has-miR-150, has-miR-31, has-miR-155, has-miR-29a, has-miR-29b, has-miR-342-5p, and has-miR-886-3p) in larger sample sets obtained from PBMCs of eleven critically ill patients with $\mathrm{H} 1 \mathrm{~N} 1$ infection and thirteen healthy controls. The expression level of the small nuclear RNU44 (RNA, U44 small nuclear) was used as the normalization control. All assays were performed in quadruplicate. Relative expression levels were calculated using the $2^{-\Delta \Delta \mathrm{Ct}}$ method. Data quantification was calculated via $t$-test between the patient and control groups using the RealTime StatMiner ${ }^{\circ}$ Software (Integromics, Spain). Twotailed $\mathrm{P}$ values $\leq 0.05$ were considered statistically significant for differences.

QRT-PCR of mRNAs was measured using an ABI Prism 7500 (Applied Biosystems, USA) and SYBR ${ }^{\circ}$ Premix Ex Taq ${ }^{\text {Th }}$ II (Takara, Japan) according to the instructions of the manufacturer. A total of $0.5 \mu \mathrm{g}$ of RNA from each sample was used to generate cDNA as templates by RT with the PrimeScript RT reagent kit (Takara, Japan). Primer pairs used for real-time PCR were shown in Table 1. The results of the qRT-PCR were normalized to $\beta$-actin expression. All assays were performed in triplicate. Relative expression levels were calculated using the $2^{-\Delta \Delta \mathrm{Ct}}$ method. Data quantification was calculated via $t$-test between the patient and control groups using the RealTime StatMiner Software. Twotailed $\mathrm{P}$ values $\leq 0.05$ were considered statistically significant.

\section{Receiver operating characteristic (ROC) analysis}

ROC curves were established to evaluate the diagnostic value of differentially expressed miRNAs for differentiating between critically ill patients and controls using Graphpad Prism software (California, USA). QRT-PCR data of the nine differentially expressed microRNAs were used for analysis. A P value of less than 0.05 was considered statistically significant. The ROC analysis tool was used to determine the sensitivity and specificity of
Table 1 qRT-PCR primers used in the study

\begin{tabular}{ll}
\hline Gene & Sequence \\
\hline TP53 & 5'-CCTCCTCAGCATCTTATCCGAGTG-3'(forward) \\
CASP3 & 5'-CCAACCTCAGGCGGCTCATAG-3'(reverse) \\
& 5'-AGAACTGGACTGTGGCATTGAG-3' (forward) \\
JAK2 & 5'-GCTTGTCGGCATACTGTTTCAG-3'(reverse) \\
& 5'-CGGTATGACCCTCTACAGGACAAC-3'(forward) \\
IL-10 & 5'-AGATTACGCCGACCAGCACTG-3'(reverse) \\
& 5'-TGCTGGAGGACTTAAGGGTACC-3' (forward) \\
MX1 & 5'-TGATGTCTGGGTCTTGGTCTCAG-3'(reverse) \\
& 5'-ACAATCAGCCTGGTGGTGGTC-3' (forward) \\
TGFBR1 & 5'-TCAAGATTCCGATGGTCCTGTCTC-3'(reverse) \\
& 5'-GCTGTGAAGCCTTGAGAGTAATGG-3' (forward) \\
MAPK14 & 5'-GATGCCTTCCTGTTGACTGAGTTG-3'(reverse) \\
& 5'-GGAGGTGCCCGAGCGTAC-3' (forward) \\
& 5'-TGGACTGAAATGGTCTGGAGAGC-3'(reverse) \\
& 5'-TGGCACCCAGCACAATGAA-3' (forward) \\
& 5'-CTAAGTCATAGTCCGCCTAGAAGCA-3'(reverse)
\end{tabular}

each possible cut-off score. The cut-off score yielding the highest sum of specificity and sensitivity was used as optimal cut-off score.

\section{MiRNA target prediction}

Different algorithms were used for miRNA target prediction, including miRanda [44], TargetScan 5.1 [45], miRDB [46], RNA22 [47], PICTAR5 [48] and miRwalk [49]. Only miRNA target genes identified by at least three of these algorithms were considered.

Thus far, a few parts of important miRNA target genes were validated in numerous studies. However, most miRNA target genes were still not validated by experiments. We obtained the validated target gene set of these differentially expressed miRNAs from miRwalk database.

\section{Protein-protein interaction}

In our study, we used the protein-protein interactions from the STRING database [50], which integrates and weighs information from numerous sources, including conserved neighborhood, gene fusions, phylogenetic cooccurrence, co-expression, database imports, large-scale experiments, and literature co-occurrence [51]. The scores higher than 0.7 will be considered as high confidence [51], thus, we used the interactions with combined scores higher than 0.7 for further analysis.

\section{Enrichment analysis and network construction}

DAVID [52], a functional annotation tool, was used to analyze the enriched KEGG [53] and REACTOME [54] pathways with default settings. The integrative network 
of miRNA-mediated host-influenza virus protein interactions was drawn using Cytoscape [55].

\section{Results}

Demographic and laboratory findings of the patients Eleven critically ill patients with no underlying diseases were included in the study. All patients were presented with influenza-like syndrome and met the diagnostic criteria of critical case. Their mean \pm SD age was $30.91 \pm$ 8.1 years; eight patients were male and three were female. The levels of body mass index (BMI) were all greater than $25 \mathrm{~kg} / \mathrm{m}^{2}$. Four of the patients were cured with noninvasive ventilation, and tracheal intubation was performed in the other seven patients. The CT scan showed that the pulmonary lesions of all patients rapidly progressed. The Mean \pm SD white blood cells were 6.31 $\pm 3.66 \mathrm{~mm}^{3}$. The laboratory findings of the patients at the time of sample collection are summarized in detail in Table 2.

Significantly differentially expressed miRNAs differentiate H1N1 critically ill patients from healthy control samples

We performed a series of microarray profiling of cellular miRNAs in PBMCs from critically ill patients infected with H1N1 influenza virus and healthy controls to identify systematic differences in miRNA expression patterns during influenza virus infection. Forty-one human miRNAs were significantly differentially expressed between $\mathrm{H} 1 \mathrm{~N} 1$ critically ill patients and healthy controls, with false discovery rate lower than 0.05 and fold change higher than 1.5 (Figure 1). The cluster analyses revealed complete separation of the patient and control groups based on the expression profiles of the differentially expressed miRNAs (Figure 2).

\section{QRT-PCR validation of differentially expressed miRNAs and ROC analysis}

The microarray data were validated by performing, qRTPCR for nine miRNAs, including hsa-miR-146b-5p, hsamiR-148a, hsa-miR-150, hsa-miR-31, hsa-miR-155, hsamiR-29a, hsa-miR-29b, hsa-miR-342-5p, and hsa-miR -886-3p. We also considered hsa-miR-148a, which has an obvious fold change, but filtered by statistics test, and was proven highly important in previous studies. Subsequently, we used scatter plot to represent the relative expression levels of these nine miRNAs (Figure 3). The qRT-PCR results were in accordance with the miRNA microarray results. The expression of hsa-miR-150, hsamiR-31, hsa-miR-155, hsa-miR-29a, hsa-miR-29b, hsamiR-342-5p, and hsa-miR-146b-5p were present in lower abundance, whereas hsa-miR-148a and hsa-miR-886-3p were present in higher abundance in PBMCs from critically ill patients infected with H1N1 influenza virus than that from healthy controls. This result indicates a positive correlation between the quantities of transcripts measured by both microarray and qRT-PCR assay (Figure 4).

ROC curve analyses revealed that miR-31, miR-29a and miR-148a were valuable biomarkers for differentiating critically ill patients from controls: miR-31 yielded

Table 2 Laboratory findings on collection day

\begin{tabular}{|c|c|}
\hline Variable & Value \\
\hline \multicolumn{2}{|l|}{ Days from in accident to in hospital } \\
\hline Mean $\pm S D-d$ & $5.19 \pm 1.94$ \\
\hline \multicolumn{2}{|l|}{ Leukocyte count } \\
\hline Mean count-per $\mathrm{mm}^{3}$ & $6.31 \pm 3.66$ \\
\hline \multicolumn{2}{|l|}{ Lymphocyte count } \\
\hline Mean count-per $\mathrm{mm}^{3}$ & $1.57 \pm 3.10$ \\
\hline \multicolumn{2}{|l|}{ Creatine kinase } \\
\hline Mean $\pm S D-U /$ liter & $871.3 \pm 1254.02$ \\
\hline >200 U/liter — no./total no. (\%) & $6 / 11(54.5)$ \\
\hline \multicolumn{2}{|l|}{ Creatine kinase $\mathrm{MB}$ fraction } \\
\hline Mean \pm SD—U/liter [total no.] & $35.4 \pm 18.16[10]$ \\
\hline$>25$ U/liter-no./total no. (\%) & $8 / 10(80.0)$ \\
\hline \multicolumn{2}{|l|}{ Lactate dehydrogenase-U/liter } \\
\hline Mean \pm SD—U/liter & $611.12 \pm 368.81$ \\
\hline \multicolumn{2}{|c|}{ C-reactive protein $>10 \mathrm{mg} /$ liter - no./total no. (\%) } \\
\hline Mean $\pm S D-U / l i t e r$ & $133.07 \pm 56.47$ \\
\hline \multicolumn{2}{|l|}{ Hydroxybutyrate dehydrogenase } \\
\hline Mean \pm SD—U/liter & $607.91 \pm 331.77$ \\
\hline
\end{tabular}




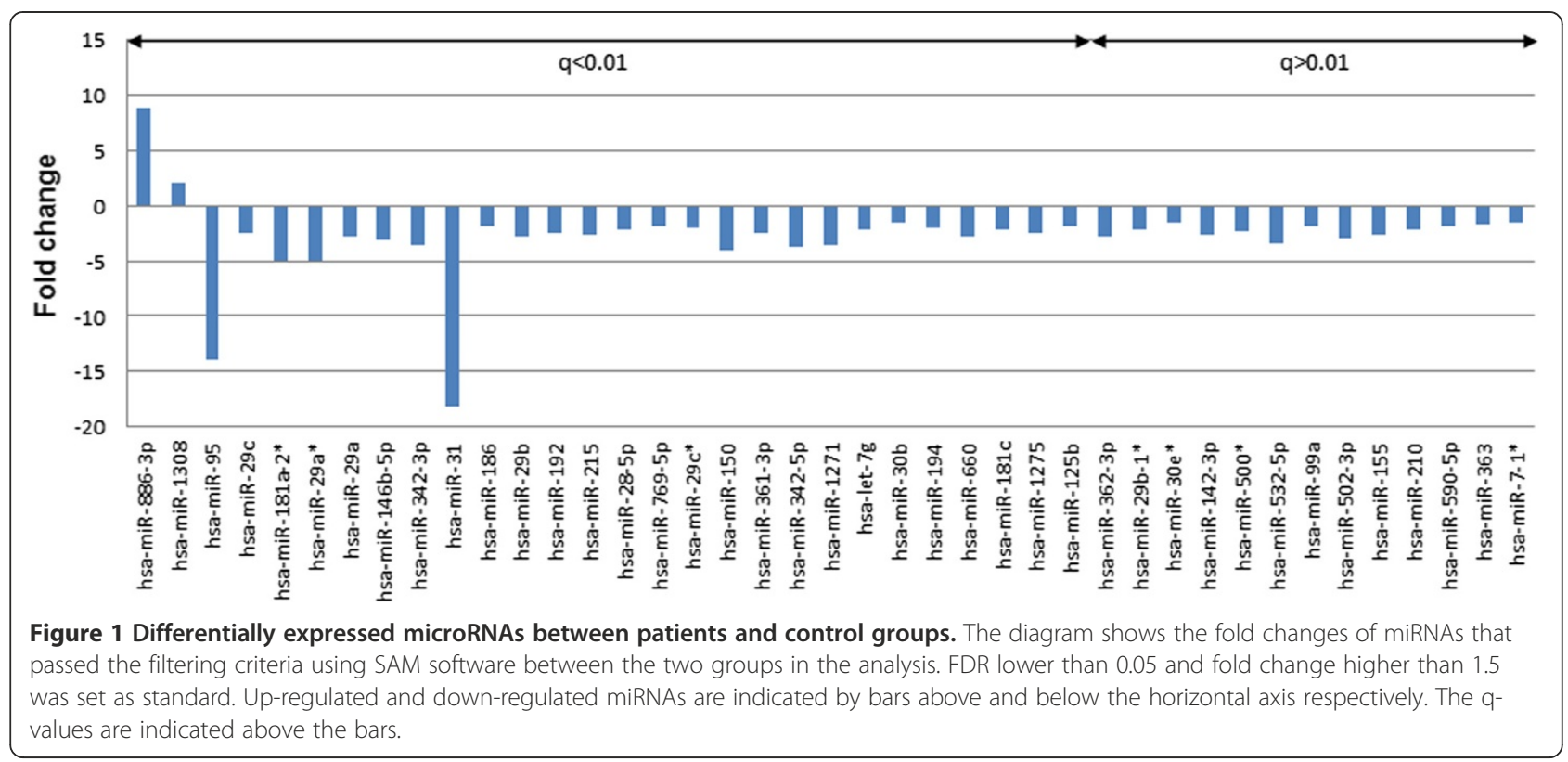

an AUC (the areas under the ROC curve) of 0.9510 (95\% CI: $0.8734-1.029$; P $=0.0001884$ ) with $81.82 \%$ sensitivity and $92.31 \%$ specificity in discriminating critically ill patients; miR-29a yielded AUC of 0.8951 (95\% CI: $0.7412-1.049 \mathrm{P}=0.0001070$ ) with $90.91 \%$ sensitivity and 92.31\% specificity in discriminating critically ill patients, and miR-148a yielded AUC of 0.8811 (95\% CI: $0.7360-$ $1.026 \mathrm{P}=0.001601$ ) with $72.73 \%$ sensitivity and $100 \%$ specificity in discriminating critically ill patients(Figure 5). However, miR-146b-5p could not discrimiate critically ill patients effectively due to the $\mathrm{P}$ value of ROC analysis was higher than 0.5(Figure 5). The result was consistent with the qRT-PCR result (Figure 3). The expression level of miR-146b-5p was only slightly decreased in critically ill patients compared to controls with no significant difference $(\mathrm{P}>0.05)$.

\section{MiRNA target prediction and qRT-PCR validation}

Numerous studies showed that miRNAs can influence gene expression by causing translational repression or mRNA degradation. This dysregulation can alter several downstream pathways and manifest effects. Therefore, miRNA gene target predictions from miRanda, Targetscan, miRDB, RNA22, PICTAR5, and miRwalk $[44,45,47-49,56]$ were performed in our study. A total of 12,117 targets with 55,838 interactions were predicted.

Interactions between proteins provide a basis for most biological processes in an organism. The topological analysis can help obtain important information in the network formed by interacting proteins. Thus, in this study, we used the protein-protein interaction data from the STRING database [50] to construct the network of the target genes of the differentially expressed miRNAs to identify several 'hub' nodes (the high connected proteins), which have an important function in influenza virus infection. This study will help in the understanding of the potential functions of the differentially expressed miRNAs.

QRT-PCR was performed for these 'hub' nodes expressed in the PBMCs from H1N1 patients $(\mathrm{n}=11)$ and normal controls $(\mathrm{n}=13)$, including tumor protein p53 (TP53, degree: 553), mitogen-activated protein kinase 14 (MAPK14, degree: 201), Janus kinase 2 (JAK2, degree: 197), caspase 3 apoptosis-related cysteine peptidase (CASP3, degree: 158), interleukin 10 (IL-10, degree: 112), transforming growth factor beta receptor 1 (TGFBR1, degree: 67), and myxovirus resistance 1 (MX1, degree: 32). We also used scatter plot to represent the relative expression levels of these seven mRNAs (Figure 6). The expression levels of JAK2, CASP3, IL-10, and MX1 significantly increased, whereas TP53 and TGFBR1 significantly decreased in PBMCs from critically ill patients infected with H1N1 influenza virus than that from healthy controls. Only a slight increase in the MAPK14 expression level was observed in PBMCs from critically ill patients with no significant difference.

\section{Integrative analysis of influenza virus-related miRNA- mRNA regulatory network}

Like all viruses, influenza virus relies on the cellular machinery of the host to support their life cycle. Tokiko Watanabe et al. [57] summarized 1,449 cellular genes identified to date as important for influenza virus replication from several RNAi-based genome-wide screening experiments. Identifying the host functions co-opted for viral replication is of interest for the understanding of 


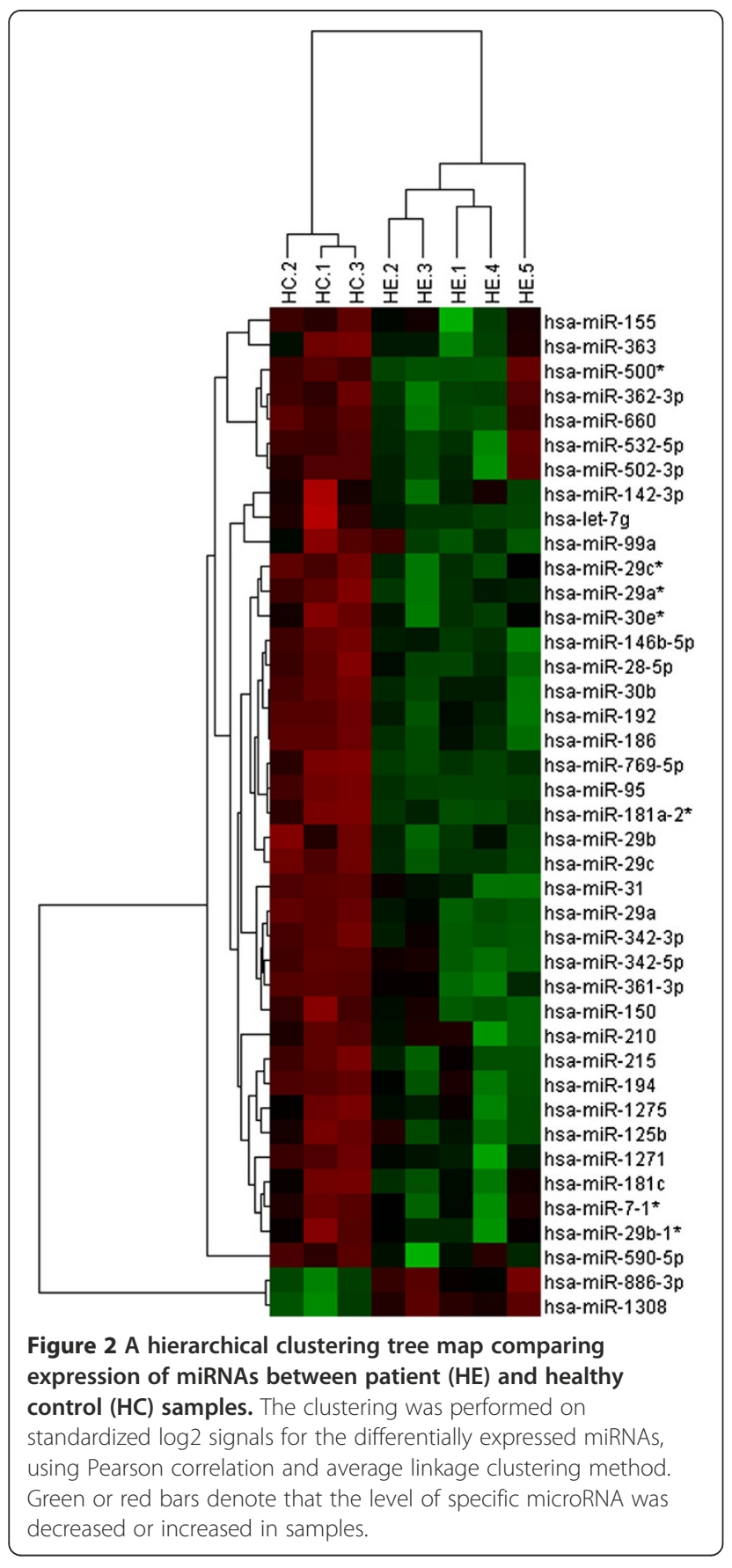

the mechanisms of the virus life cycle and to find valuable targets of differentially expressed miRNAs in our study. We obtained the data of virus-host interactions from previous studies [6,7], which can provide more insights into the molecular mechanism of diseases at systematic level.

Functional enrichment analysis $(\mathrm{P}<0.05)$ performed to these cellular genes revealed various over-represented pathways, including the MAPK signaling pathway, Tolllike receptor signaling pathway, B cell receptor signaling pathway, $\mathrm{T}$ cell receptor signaling pathway, Wnt signaling pathway, chemokine signaling pathway, apoptosis, Jak-STAT signaling pathway, epidermal growth factor receptor (EGFR) signal pathway, mTOR signal pathway, and TGF-beta signaling pathway, which are critical cellular pathways related to virus infection.

Among these cellular genes, we summarized the interactions between nodes in these enriched KEGG pathways to construct a combined pathway network. Topological analysis was then performed to determine which nodes can be major regulators and receivers. A major regulator is defined as a node that exerts control over at least five other nodes, whereas a major receiver is influenced by a minimum of five nodes. The nodes with a degree of more than 3 in the combined network were selected to form a subnetwork for further analysis, in which we added the data of miRNAs who have targets validated by previous studies or predicted by a large number of algorithms on the major regulators and receivers. With the additional data of virus-host interactions, we were able to construct Figure 7.

Our data suggest that miRNA dysregulation in the PBMCs of H1N1 critically ill patients can regulate a number of key genes in the major signaling pathways associated with influenza virus infection.

\section{Discussion}

MiRNAs have been reported to participate in regulating cross-talk between the host and the pathogen in viral infections, which have a major function in viral pathogenesis [12-14]. Cellular miRNAs can also be involved in regulating the molecular pathways of innate and adaptive immune responses, and can act as an antiviral defense mechanism or even inhibit virus replication directly $[58,59]$. Cellular miRNAs can be used by viruses for their own advantage. For example, the hepatitis $\mathrm{C}$ virus $(\mathrm{HCV})$ replication is dependent on cellular miR122 expression. The HCV RNA genome contains two miR-122 binding sites in its 5'UTR, which are required to activate viral genomic RNA replication. Increased miR-122 expression can result in regulating antiapoptotic genes and enhancing viral replication to promote cell proliferation [60-62].

In our study, we used PBMC cell samples from critically ill patients with H1N1 influenza and identified numerous differentially expressed miRNAs (Figure 1). QRT-PCR assay and ROC curve analyses revealed that miR-31, miR-29a and miR-148a all had significant potential diagnostic value for critically ill patients infected with H1N1 influenza virus, which yielded AUC of 0.9510, 0.8951 and 0.8811, respectively (Figures 3 and 5). Some of these differentially expressed miRNAs via in silico analysis targeted mRNAs of several key genes, including TP53, CASP3, JAK2, IL-10, MX1, TGFBR1, and 

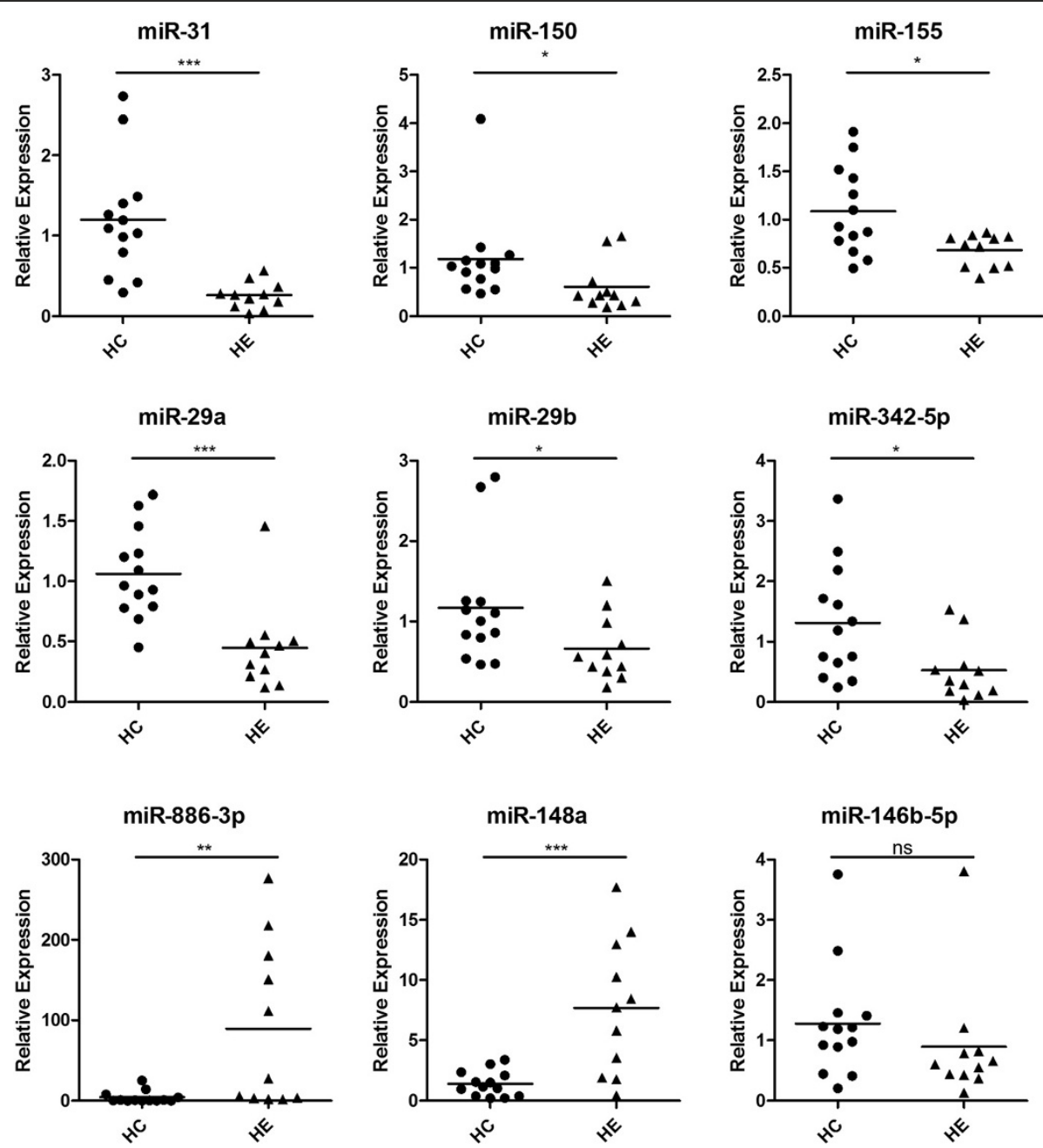

Figure 3 qRT- PCR analysis of 9 miRNAs expression in the PBMCs from patients with H1N1 $(n=11)$ and normal controls $(n=13)$. qRTPCR analysis of 9 miRNAs expression in the PBMCs from H1N1 critically ill patients ( $n=11 ; 8$ male 3 female; age $31 \pm 8$ y [mean \pm SD]) and healthy controls $(n=13 ; 9$ male 4 female; age $29 \pm 5$ y [mean \pm SD]). The relative expression levels were normalized to the expression of RNU44. HE: H1N1 critically ill patients $\mathrm{HC}$ : healthy controls. * $\mathrm{P}<0.05$; ${ }^{*} \mathrm{P}<0.01$; ${ }^{* * *} \mathrm{P}<0.005$.

MAPK14. These changes affect numerous other genes and regulators of metabolism and signaling pathways. These subset gene changes are crucial to H1N1 infection and are responsible for disease progression.

MiR-29a and miR-29b were reported to be downregulated in lung tissues from mice infected with reconstructed 1918 or a nonlethal seasonal influenza virus, Tx/91 [17]. This was consistent with our result. Both miR-29a and miR-29b could repress IFN-gamma production by direct targeting of both T-box transcription factor T-bet and Eomesodermin (Eomes), two transcription factors known to induce IFN-gamma production [63]. Therefore, the downregulated miR-29 may regulate the $\mathrm{T}$ helper 1 (Th1) cell differentiation to secrete more IFN-gamma and mediate elimination of intracellular pathogens, but dysregulated $\mathrm{T}$ cell responses may also contribute to pathologic inflammation.
E. K. Loveday et al. demonstrated that miR-29a, miR$29 \mathrm{c}$ and let-7g were down-regulated in human A549 cells infected with swine-origin influenza pandemic H1N1 [21]. This was consistent with our result. Let-7g could inhibit lectin-like oxidized low-density lipoprotein receptor-1 expression and inhibits apoptosis, by which may suggest increased cell apoptosis [64]. Moreover, let$7 \mathrm{~g}$ could inhibit the expression of IL-13, a key inducer of airway inflammation secreted by $\mathrm{TH} 2$ lymphocytes and other cells $[65,66]$. Therefore, down-regulation of miR$29 \mathrm{a}$, miR-29c and let-7g may contribute to the uncontrolled inflammation by allowing up-regulation of proinflammation genes.

The critically ill patients in this study all had no underlying diseases including type 2 diabetes, immunodeficiency or cardiopulmonary diseases, but they had comorbidities like pneumonia or acute respiratory 


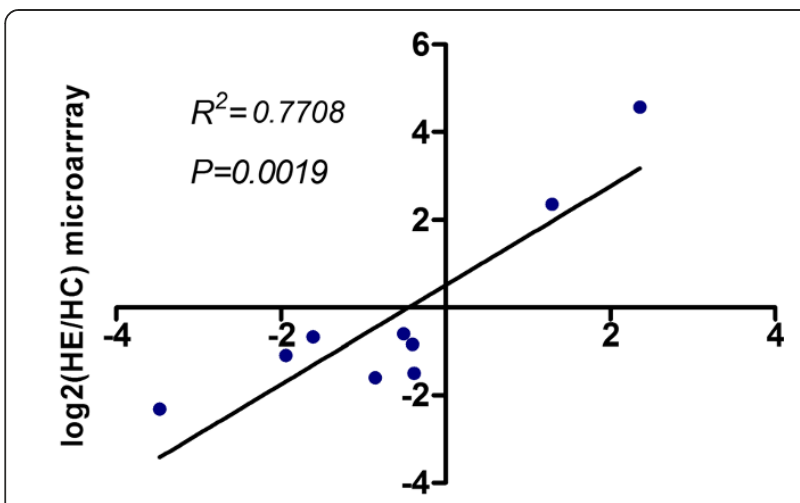

$\log 2(\mathrm{HE} / \mathrm{HC}) \mathrm{qPCR}$

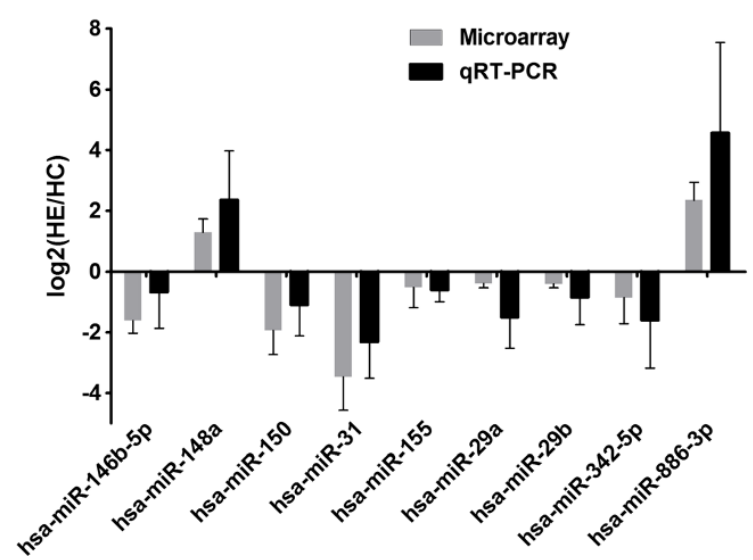

Figure 4 Comparison of miRNA expression levels obtained by miRNA microarray and Taqman qRT-PCR analysis.

distress syndrome (ARDS), which may lead to disease progression. We collected samples as soon as patients were admitted to ICU with confirmed influenza A H1N1 infection, when they were very severe and immediately treated with anti-infective therapy and so on. Interestingly, we found all the critically ill patients in our study were overweight $\left(\mathrm{BMI}>25 \mathrm{~kg} / \mathrm{m}^{2}\right)$. Many reports support the view that obesity is associated with higher risks of ICU admission and death in patients with influenza A (H1N1) infection [67-69]. Other findings suggest that obese patients with severe infection were more likely to develop pneumonitis compared to non-obese patients [70-72]. Infection with influenza virus in diet-induced obese mice was shown to dysregulate immune response, expecially impair the $\mathrm{T}$ cell memory response, and lead to increased morbidity and mortality from viral infection [73-75]. A recent study reported that the expression of miR-146b-5p was decreased in monocytes during obesity [76]. MiR-146b-5p acts as an inhibitor of NF-kB-mediated inflammation and is necessary for the anti-inflammatory action of high levels of globular adiponectin. Another group found that let-7g was downregulated in the fetal muscle of diet-induced obese ovine compared to control. The downregulation of let-7g may enhance intramuscular adipogenesis during fetal muscle development in the setting of maternal obesity [77]. Taken together, our findings suggest the downregulation of miR-146b-5p and let-7g were important in further understanding the molecular mechanisms implicated in obese patients susceptive to severe infection of H1N1 influenza virus.

Schmidt et al. [78] found that miR-146b-5p, miR-150, miR-342-3p and let-7g were downregulated in peripheral blood leukocytes during acute lipopolysaccharide (LPS) induced inflammation, which was similar to our result. Several genes encoding proteins involved in NF- $\mathrm{KB}$ and MAPK signaling as well as cytokine pathways and other inflammation pathways were predicted targets of these LPS-responsive miRNAs. These miRNAs may play an important role in controlling the level of inflammatory response. A predisposition for pneumococcal infections after H1N1 influenza virus infection has been reported [79]. Streptococcus pneumonia co-infection is correlated with the morbidity and the mortality of $\mathrm{H} 1 \mathrm{~N} 1$ pandemic influenza [80]. Therefore, this result is reasonable because most of our patients had pulmonary infections.

The p38 MAPK are a class of MAPKs.kinases. The p38 MAPK pathway is strongly activated by stress, but also has important functions in the immune response and in regulating cell survival and differentiation, which allows cells to interpret a wide range of external signals and respond appropriately by generating a large number of different biological effects [81]. Studies have shown that influenza virus infection activates MAPK family members in mammals, and the expression of RANTES, IL-8, and tumor necrosis factor-alpha were controlled by $\mathrm{p} 38$ activation [82]. P38 MAPK is a determinant of virus infection, which depends on MyD88 expression and Toll-like receptor 4 (TLR4) ligation, and the inhibition of p38 MAPK signaling significantly inhibits virus replication [83]. However, in our study, MAPK14 mRNA expression in critically ill patients had no significant change compared with healthy controls, indicating that the response and the regulation of key gene expression for survival in H1N1 critically ill patients is highly complex. P38 MAPKs (MAPK11, MAPK13, and MAPK14) were found to be regulated by miR-769-5p, miR-146b-5p, let-7g, miR-30b, miR-31, miR-361-3p, and miR-362-3p (Figure 7), which were all down expressed in H1N1 critically ill patients. Thus, increasing the expression of miRNAs targeting p38 MAPKs in H1N1 critically ill patients can help inhibit virus replication. These miRNAs can have an antiviral function during influenza virus infection.

We found that EGFR was regulated by miR-342, miR155, miR-30b, miR-210, miR-192, let-7g, and miR-146b $-5 \mathrm{p}$, which were all down expressed in H1N1 critically ill 


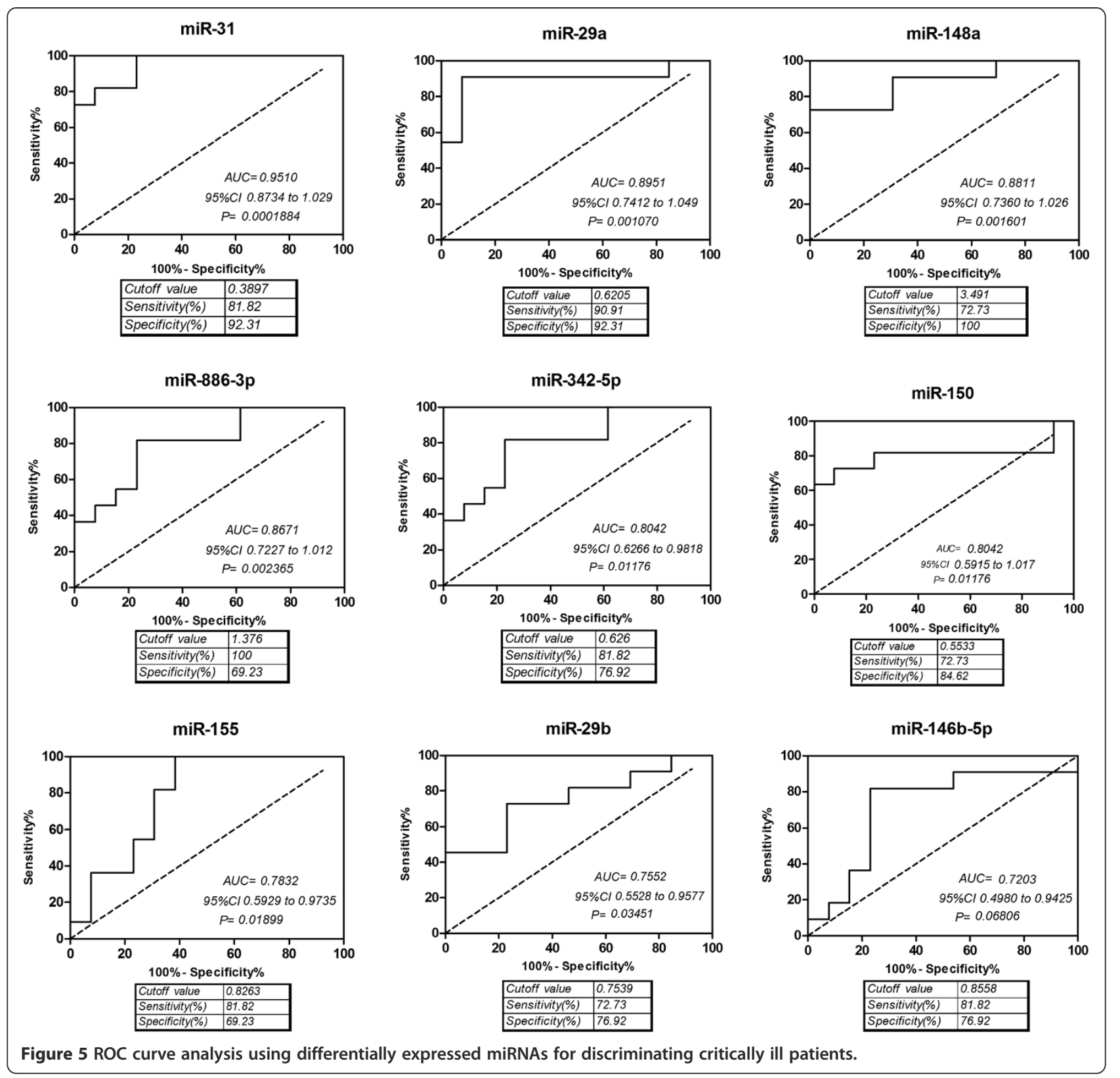

patients. EGFR can promote the uptake of influenza viruses into host cells by forming a lipid raft-based signaling platform with sialic acids and other receptor tyrosine kinases (RTKs) [84]. These downregulated miRNAs can upregulate EGFR expression, resulting in easier virus replication and propagation at the early stage of infection. This result is additionally supported by that of a recent siRNA screening study, which identified the fibroblast growth factor receptors 1,2 , and 4 as RTKs involved in the early stages of viral infection [6]. The downregulation of this kind of miRNAs helps to regulate the host antiviral response or to benefit the virus by allowing virus replication.

Apoptosis is a hallmark event observed in infection with numerous viral pathogens, including influenza A virus
[85]. Sequential activation of caspases can have a central function in the execution phase of cell apoptosis. CASP3 is a major virus-induced apoptosis effector, which can be activated by CASP9 (Figure 7). A previous study showed that the presence of inhibitor that blocks CASP3 or knock-down of CASP3 by siRNAs can significantly impair influenza virus propagation, proving the importance of CASP3 activation for efficient influenza virus replication during the onset of apoptosis [85]. In our study, CASP3 was significantly upregulated by qRT-PCR analysis (Figure 6) and targeted by the downregulated miRNAs: miR342-3p, miR-29b, miR-29c, miR-29a, let-7g and miR-30b, which can be expected to develop miRNA-based therapeutics for influenza disease. 

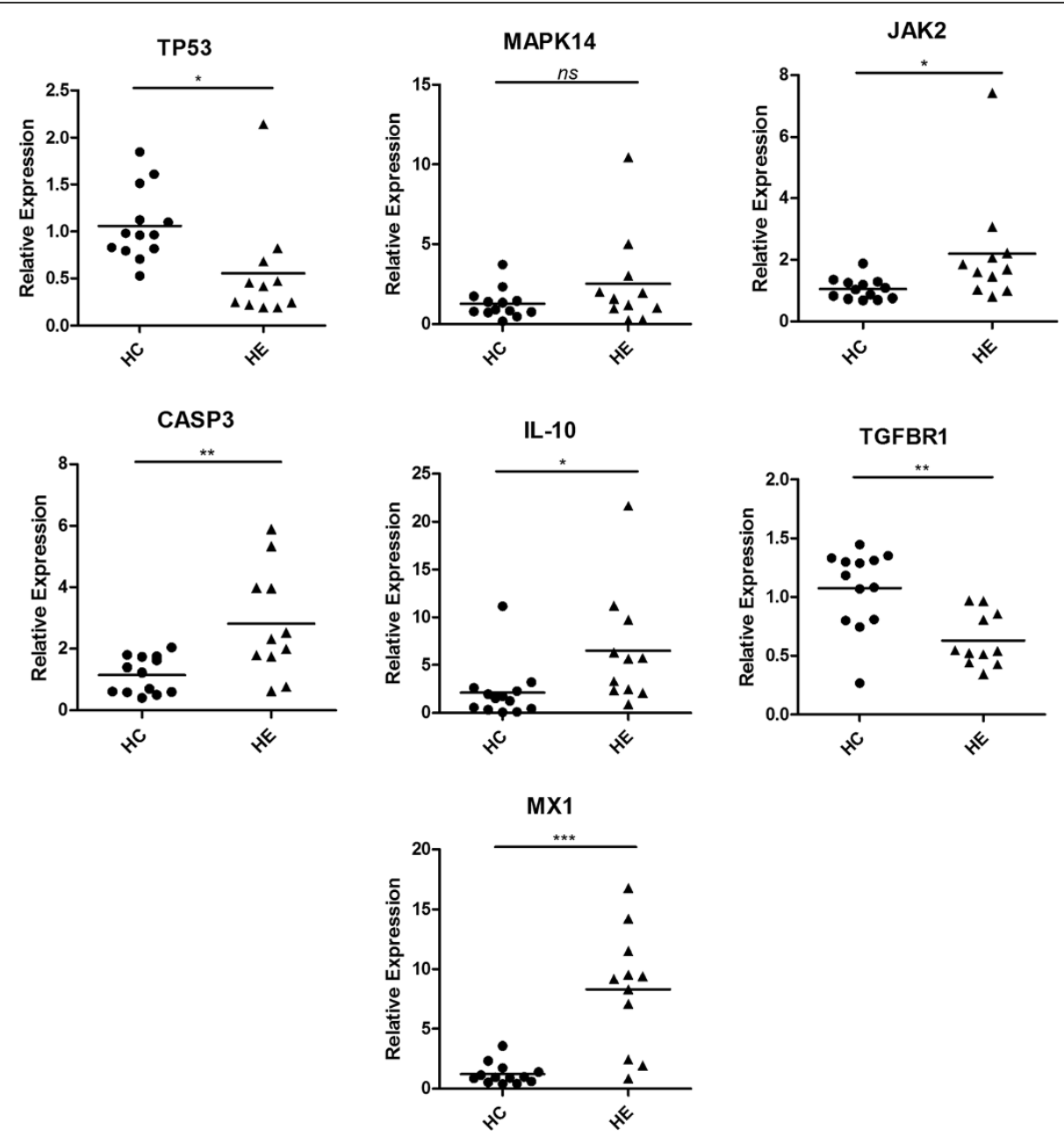

Figure 6 qRT- PCR analysis of 6 mRNAs expressed in the PBMCs from patients with H1N1 $(n=11)$ and normal controls $(n=13)$. The relative expression levels were normalized to the expression of $\beta$-actin. $\mathrm{HE}$ : $\mathrm{H} 1 \mathrm{~N} 1$ critically ill patients $\mathrm{HC}$ : healthy controls. ${ }^{*} \mathrm{P}<0.05$; ${ }^{* *} \mathrm{P}<0.01$; ***P $<0.005$.

Transforming growth factor beta (TGF-beta) is a family of proteins secreted by virtually all cells. TGF-beta levels increase during viral infection, and significant TGF-beta levels activated by influenza virus exist to induce cell apoptosis [86]. In our study, TGF-beta receptor 1 (TGFBR1) was found to be downregulated (Figure 6). TP53 is a wellknown tumor suppressor that responds to diverse cellular stresses to regulate target genes that induce cell cycle arrest, apoptosis, and senescence. TP53 was also found to be downregulated. A response mechanism of host cell possibly exists to remit apoptosis induced by influenza virus. Moreover, TGFBR1 and TP53 were both predicted to be regulated by high-expressed miR-148a.

We found that miR-148a was significantly upregulated compared with the control samples by qRT-PCR assay, indicating that miR-148a has an important function in influenza virus infection. MiR-148a has been associated with different types of cancer $[87,88]$ and autoimmune diseases, such as multiple sclerosis [23], asthma [89] and systemic lupus erythematosus [90]. A recent study has demonstrated that miR-148a expression is also upregulated in DCs on maturation and activation induced by TLR3, TLR4, and TLR9 agonists, which, in turn, inhibit the upregulation of MHC class II expression, the production of cytokines including IL-12, IL-6, TNF-alpha, and IFNbeta, and antigen presentation of DCs by directly targeting Calcium/calmodulin-dependent protein kinase II [91]. Their result indicates that miR-148a is a negative regulator of the innate response and antigen presenting capacity of DCs. The upregulated miR-148a in PBMCs of H1N1 critically ill patients may contribute to the regulation of innate and adaptive immune responses.

Our miRNA microarray and RT-PCR analysis revealed that miR-31 was significantly down-expressed in PBMCs of H1N1 critically ill patients. MiR-31 can negatively regulate FOXP3 expression by binding directly to its 


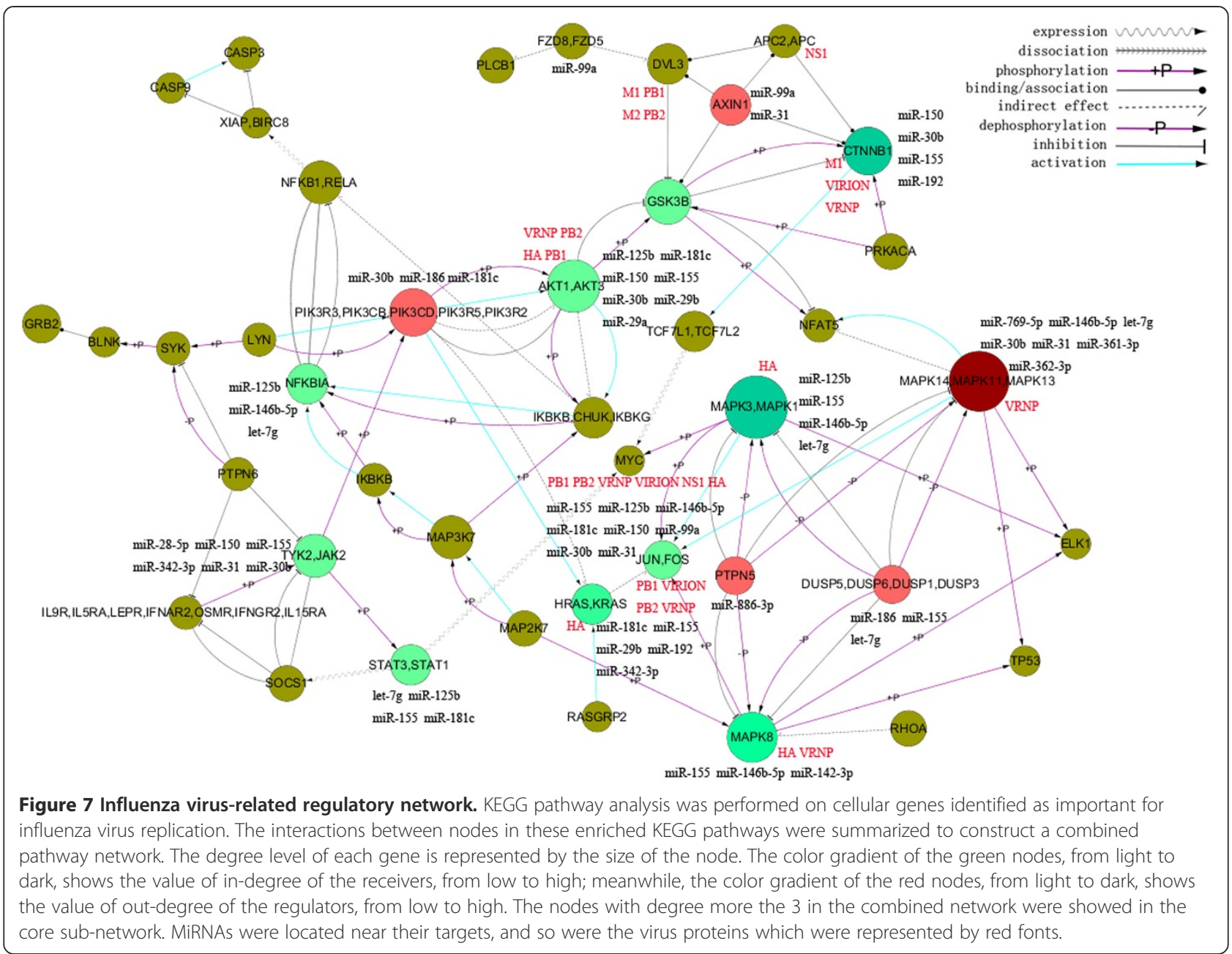

potential target site in the 3'UTR of FOXP3 mRNA [92]. Foxp3+ T regulatory (Treg) cells have an important function in inducing and maintaining immunological tolerance [93]. FoxP3+ Treg cell was significantly increased among H1N1- infected patients compared with normal controls by flow cytometry analysis $[79,94]$. The inverse correlation between miR-31 expression and Treg cell number in the PBMC of H1N1 critically ill patients can be explained by the negative regulation of FOXP3 expression.

Mx1 protein was proven highly important for longterm protection against influenza virus infection [95-97]. Recently, Cilloniz et al. found that $\mathrm{Mx} 1+/+$ mice can generate a protective antiviral response by controlling the expression of key modulator molecules associated with influenza virus lethality [98]. In our study, we found that Mx1 mRNA was significantly upregulated in H1N1 critically ill patients by qRT-PCR assay. No validated miRNA targeting Mx1 has been reported; thus, our miRNA target prediction result indicated that Mx1 can be negatively regulated by miR-342-3p and miR-210, which were both down expressed in H1N1 critically ill patients. Therefore, increasing the Mx1 expression by inhibiting these two miRNAs can enhance protection against influenza virus infection.

Adopting a global perspective is important when investigating infections. A systems biology approach to infectious disease research, which models various interacting component networks, will permit greater understanding of the molecular mechanism and the interplay between the host and pathogen. In our study, with integrated various information (miRNA targets, miRNA-mediated pathways, virus proteins, et al.), we obtained a combined network of core information related to $\mathrm{H} 1 \mathrm{~N} 1$ infection. A better understanding of the network of genes and cellular pathways regulated by these miRNAs will undoubtedly enable us to characterize the host antiviral mechanism comprehensively and to find new targets for developing antiviral compounds.

Although the results of our study can lead to understanding further the functions of miRNAs in influenza virus infection, additional experiments, such as miRNA 
target validation, in vivo western blot, and pull-down assays during infection and larger cohort of patients clinical investigation are still needed to validate and to refine our observations.

\section{Conclusions}

We identified the systematic differences in miRNA expression patterns between PBMCs from H1N1 critically ill patients and healthy controls. Using RT-PCR analysis, we verified nine important differentially expressed miRNAs and validated seven core genes. ROC curve analyses revealed that miR-31, miR-29a and miR-148a all had significant potential diagnostic value for critically ill patients infected with H1N1 influenza virus, which yielded AUC of $0.9510,0.8951$ and 0.8811 , respectively. In addition, we found that a number of genes and signaling pathways that are important to influenza virus infection are likely to be regulated, at least partly, by miRNAs. Finally, we constructed an influenza virus-related miRNA-mRNA regulatory network, which can lead to a global perspective for investigating influenza virus infection.

Therefore, further understanding the functions of these miRNAs in influenza virus infection will provide new insight into the host-pathogen interactions and pathogenesis.

\begin{abstract}
Abbreviations
miRNA: MicroRNA; PBMC: Peripheral blood mononuclear cell; WHO: World health organization; RNAi: RNA interference; DC: Dendritic cell; NK: Natural killer; ICU: Intensive care unit; CK: Creatine kinase; CK-MB: Creatine kinase isoenzyme; CDC: Center for prevention and disease control; BMI: Body mass index; TP53: Tumor protein p53; MAPK14: Mitogen-activated protein kinase 14; JAK2: Janus kinase 2; CASP3: Caspase 3 apoptosis-related cysteine peptidase; IL10: Interleukin 10; TGFBR1: Transforming growth factor beta receptor 1; Mx1: Myxovirus resistance 1; EGFR: Epidermal growth factor receptor; ROC: Receiver operating characteristic; AUC: The areas under the ROC curve; BMI: Body mass index.
\end{abstract}

\section{Competing interests}

All authors declare that they have no competing interests.

\section{Authors' contributions}

Conceived and designed the experiments: HS QW DZ JC. Performed the experiments: HS QW YG. Analyzed the data: HS YG LD. Contributed reagents/ materials/analysis tools: SL XG RS BL. Wrote the paper: HS YG QW DZ JC. All authors read and approved the final manuscript.

\section{Acknowledgements}

This work was supported by National Natural Science Foundation of China (No. 31072115). Support was also provided by a National Key Technology R\&D Program in the 11th Five year Plan of China (No. 2009ZX10004-105) and Science and Technology Project of Beijing, China (No. D09050703560908).

\section{Author details}

'MOA Key Laboratory of Animal Biotechnology of National Ministry of Agriculture, Institute of Veterinary Immunology, and Research Laboratory of Virology, Immunology \& Bioinformatics, Division of Veterinary Microbiology \& Virology, Department of Preventive Veterinary Medicine, College of Veterinary Medicine, Northwest A \& F University, Yangling, 712100, Xi'an City, Shaanxi Province, China. ${ }^{2}$ Institute of Infectious Diseases, Beijing Ditan Hospital, Capital Medical University, Beijing 100015, China. ${ }^{3}$ Beijing Key Laboratory of Emerging Infectious Diseases, Beijing 100015, China.

${ }^{4}$ Investigation Group of Molecular Virology, Immunology, Oncology \&
Systems Biology, Center for Bioinformatics, College of Life Sciences, Northwest A \& F University, Yangling, 712100, Xi'an City, Shaanxi Province, China. ${ }^{5}$ Department of Infectious Diseases, Beijing Ditan Hospital, Capital Medical University, Beijing 100015, China.

Received: 18 September 2012 Accepted: 30 May 2013 Published: 3 June 2013

\section{References}

1. Butler D: Portrait of a year-old pandemic. Nature 2010, 464(7292):11121113.

2. Huarte M, Sanz-Ezquerro JJ, Roncal F, Ortin J, Nieto A: PA subunit from influenza virus polymerase complex interacts with a cellular protein with homology to a family of transcriptional activators. J Virol 2001, 75(18): 8597-8604.

3. Hao L, Sakurai A, Watanabe T, Sorensen E, Nidom CA, Newton MA, Ahlquist P, Kawaoka Y: Drosophila RNAi screen identifies host genes important for influenza virus replication. Nature 2008, 454(7206):890-893.

4. Karlas A, Machuy N, Shin Y, Pleissner KP, Artarini A, Heuer D, Becker D, Khalil $H$, Ogilvie LA, Hess S, et al: Genome-wide RNAi screen identifies human host factors crucial for influenza virus replication. Nature 2010, 463(7282): 818-822.

5. Brass AL, Huang IC, Benita Y, John SP, Krishnan MN, Feeley EM, Ryan BJ, Weyer $J \mathrm{~L}$, van der Weyden L, Fikrig E, et al: The IFITM proteins mediate cellular resistance to influenza a H1N1 virus, west Nile virus, and dengue virus. Cell 2009, 139(7):1243-1254.

6. Konig R, Stertz S, Zhou Y, Inoue A, Hoffmann HH, Bhattacharyya S, Alamares $J G$, Tscherne DM, Ortigoza MB, Liang YH, et al: Human host factors required for influenza virus replication. Nature 2010, 463(7282):813-817.

7. Shapira SD, Gat-Viks I, Shum BOV, Dricot A, de Grace MM, Wu LG, Gupta PB, Hao T, Silver SJ, Root DE, et al: A physical and regulatory Map of hostinfluenza interactions reveals pathways in H1N1 infection. Cell 2009, 139(7):1255-1267.

8. O'Connell RM, Rao DS, Chaudhuri AA, Baltimore D: Physiological and pathological roles for microRNAs in the immune system. Nat Rev Immunol 2010, 10(2):111-122.

9. Ren JQ, Jin P, Wang E, Marincola FM, Stroncek DF: MicroRNA and gene expression patterns in the differentiation of human embryonic stem cells. J Trans Med 2009, 7:20.

10. Ji JF, Shi J, Budhu A, Yu ZP, Forgues M, Roessler S, Ambs S, Chen YD, Meltzer PS, Croce CM, et al: MicroRNA expression, survival, and response to interferon in liver cancer. N Eng J Med 2009, 361(15):1437-1447.

11. Lodish HF, Zhou B, Liu G, Chen CZ: Micromanagement of the immune system by microRNAs. Nat Rev Immunol 2008, 8(2):120-130.

12. Umbach $J$, Cullen BR: The role of RNAi and microRNAs in animal virus replication and antiviral immunity. Genes Dev 2009, 23(10):1151-1164.

13. Ouellet $D L$, Provost $P$ : Current knowledge of MicroRNAs and noncoding RNAs in virus-infected cells. Methods Mol Biol (Clifton, NJ) 2010, 623:35-65.

14. Cullen BR: Five questions about viruses and MicroRNAs. PLoS Pathog 2010, 6(2):e1000787.

15. Wang Y, Brahmakshatriya V, Zhu HF, Lupiani B, Reddy SM, Yoon BJ, Gunaratne PH, Kim JH, Chen R, Wang JJ, et al: Identification of differentially expressed miRNAs in chicken lung and trachea with avian influenza virus infection by a deep sequencing approach. BMC Genomics 2009, 10(1):512.

16. Wang $Y$, Brahmakshatriya V, Lupiani B, Reddy SM, Soibam B, Benham AL, Gunaratne P, Liu HC, Trakooljul M, Ing N, et al: Integrated analysis of microRNA expression and mRNA transcriptome in lungs of avian influenza virus infected broilers. BMC Genomics 2012, 13(1):278.

17. Li Y, Chan EY, Li J, Ni C, Peng X, Rosenzweig E, Tumpey TM, Katze MG: MicroRNA expression and virulence in pandemic influenza virus-infected mice. J Virol 2010, 84(6):3023-3032

18. Rogers JV, Price JA, Wendling MQ, Long JP, Bresler HS: Preliminary microRNA analysis in lung tissue to identify potential therapeutic targets against H5N1 infection. Viral Immunol 2012, 25(1):3-11.

19. Song LP, Liu H, Gao SJ, Jiang W, Huang WL: Cellular MicroRNAs inhibit replication of the H1N1 influenza a virus in infected cells. J Virol 2010, 84(17):8849-8860.

20. Meliopoulos VA, Andersen LE, Brooks P, Yan X, Bakre A, Coleman JK, Tompkins SM, Tripp RA: MicroRNA regulation of human protease genes essential for influenza virus replication. PLoS One 2012, 7(5):e37169. 
21. Loveday EK, Svinti V, Diederich S, Pasick J, Jean F: Temporal- and strainspecific host microRNA molecular signatures associated with swineorigin $\mathrm{H} 1 \mathrm{~N} 1$ and avian-origin H7N7 influenza A virus infection. J Virol 2012, 86(11):6109-6122.

22. Shou JY, Bull CM, Li L, Qian HR, Wei T, Luo SA, Perkins D, Solenberg PJ, Tan $S L$, Chen XYC, et al: Identification of blood biomarkers of rheumatoid arthritis by transcript profiling of peripheral blood mononuclear cells from the rat collagen-induced arthritis model. Arthritis Res Ther 2006, $8(1): R 28$

23. Otaegui D, Baranzini SE, Armananzas R, Calvo B, Munoz-Culla M, Khankhanian P, Inza I, Lozano JA, Castillo-Trivino T, Asensio A, et al: Differential micro RNA expression in PBMC from multiple sclerosis patients. PLoS One 2009, 4(7):e6309.

24. Shao HW, Lan DM, Duan ZH, Liu ZH, Min J, Zhang LC, Huang J, Su J, Chen $\mathrm{SW}, \mathrm{Xu}$ AL: Upregulation of mitochondrial gene expression in PBMC from convalescent SARS patients. J Clin Immunol 2006, 26(6):546-554.

25. Rollins B, Martin MV, Morgan L, Vawter MP: Analysis of whole genome biomarker expression in blood and brain. Am J Med Gen Part BNeuropsych Gen 2010, 153B(4):919-936.

26. Monaco A, Marincola FM, Sabatino M, Pos Z, Tornesello ML, Stroncek DF, Wang E, Lewis GK, Buonaguro FM, Buonaguro L: Molecular immune signatures of HIV-1 vaccines in human PBMCs. FEBS Lett 2009, 583(18): 3004-3008.

27. Li J, Yu YJ, Feng L, Cai XB, Tang HB, Sun SK, Zhang HY, Liang JJ, Luo TR: Global transcriptional profiles in peripheral blood mononuclear cell during classical swine fever virus infection. Virus Res 2010, 148(1-2):60-70.

28. Huang C, Chen HG, Cassidy W, Howell CD: Peripheral blood gene expression profile associated with sustained virologic response after peginterferon plus ribavirin therapy for chronic hepatitis-C genotype 1. J Nat Med Assoc 2008, 100(12):1425-1433

29. Ramilo O, Allman W, Chung W, Mejias A, Ardura M, Glaser C, Wittkowski KM, Piqueras B, Banchereau J, Palucka AK, et al: Gene expression patterns in blood leukocytes discriminate patients with acute infections. Blood 2007, 109(5):2066-2077.

30. Zaas AK, Chen MH, Varkey J, Veldman T, Hero AO, Lucas J, Huang YS, Tumer R, Gilbert A, Lambkin-Williams R, et al: Gene expression signatures diagnose influenza and other symptomatic respiratory viral infections in humans. Cell Host Microbe 2009, 6(3):207-217.

31. Zaas AK, Aziz H, Lucas J, Perfect JR, Ginsburg GS: Blood gene expression signatures predict invasive candidiasis. Sci Trans Med 2010, 2(21):21ra17.

32. Aziz H, Zaas A, Ginsburg GS: Peripheral blood gene expression profiling for cardiovascular disease assessment. Genomic Med 2007, 1:105-112.

33. Taurino C, Miller WH, McBride MW, McClure JD, Khanin R, Moreno MU, Dymott JA, Delles C, Dominiczak AF: Gene expression profiling in whole blood of patients with coronary artery disease. Clin Sci 2010, 119(78):335-343.

34. Osterlund $\mathrm{P}$, Pirhonen J, Ikonen N, Ronkko E, Strengell M, Makela SM, Broman M, Hamming OJ, Hartmann R, Ziegler T, et al: Pandemic H1N1 2009 influenza a virus induces weak cytokine responses in human macrophages and dendritic cells and is highly sensitive to the antiviral actions of interferons. J Virol 2010, 84(3):1414-1422.

35. Peiris JSM, Cheung CY, Leung $\mathrm{CYH}$, Nicholls JM: Innate immune responses to influenza A H5N1: friend or foe? Trends Immunol 2009, 30(12):574-584.

36. Arankalle VA, Lole KS, Arya RP, Tripathy AS, Ramdasi AY, Chadha MS, Sangle $S A$, Kadam DB: Role of host immune response and viral load in the differential outcome of pandemic H1N1 (2009) influenza virus infection in Indian patients. PLoS One 2010, 5(10):e13099.

37. Liu L, Zhang RF, Lu HZ, Lu SH, Huang Q, Xiong YY, Xi XH, Zhang ZY: Sixtytwo severe and critical patients with 2009 influenza $A$ (H1N1) in Shanghai. China. Chin Med J 2011, 124(11):1662-1666.

38. WHO website: CDC protocol of real time RT-PCR for influenza A (H1N1). ; 2009. http://www.who.int/csr/resources/publications/swineflu/realtimeptpcr/en/ index.html.

39. Griffiths-Jones S, Saini HK, van Dongen S, Enright AJ: miRBase: tools for microRNA genomics. Nucleic Acids Res 2008, 36:D154-D158.

40. Tusher VG, Tibshirani R, Chu G: Significance analysis of microarrays applied to the ionizing radiation response. Proc Natl Acad Sci USA 2001, 98(9):5116-5121.

41. de Hoon MJL, Imoto S, Nolan J, Miyano S: Open source clustering software. Bioinformatics 2004, 20(9):1453-1454
42. Saldanha AJ: Java Treeview-extensible visualization of microarray data. Bioinformatics 2004, 20(17):3246-3248.

43. Barrett T, Troup DB, Wilhite SE, Ledoux P, Rudnev D, Evangelista C, Kim IF, Soboleva A, Tomashevsky M, Marshall KA, et al: NCBI GEO: archive for highthroughput functional genomic data. Nucleic Acids Res 2009, 37(Database issue):D885-890.

44. John B, Enright AJ, Aravin A, Tuschl T, Sander C, Marks DS: Human MicroRNA targets. PLoS Biol 2004, 2(11):1862-1879.

45. Friedman RC, Farh KK-H, Burge CB, Bartel DP: Most mammalian mRNAs are conserved targets of microRNAs. Gen Res 2009, 19(1):92-105.

46. Wang XW: miRDB: A microRNA target prediction and functional annotation database with a wiki interface. RNA-Publ RNA Soc 2008 14(6):1012-1017

47. Miranda KC, Huynh T, Tay Y, Ang YS, Tam WL, Thomson AM, Lim B, Rigoutsos I: A pattern-based method for the identification of MicroRNA binding sites and their corresponding heteroduplexes. Cell 2006, 126(6):1203-1217.

48. Krek A, Grun D, Poy MN, Wolf R, Rosenberg L, Epstein EJ, MacMenamin P, da Piedade I, Gunsalus KC, Stoffel M, et al: Combinatorial microRNA target predictions. Nat Genet 2005, 37(5):495-500.

49. Dweep H, Sticht C, Pandey P, Gretz N: MiRWalk - database: prediction of possible miRNA binding sites by "walking" the genes of three genomes. J Biomed Info 2011, 44(5):839-847.

50. Szklarczyk D, Franceschini A, Kuhn M, Simonovic M, Roth A, Minguez P, Doerks T, Stark M, Muller J, Bork P, et al: The STRING database in 2011: functional interaction networks of proteins, globally integrated and scored. Nucleic Acids Res 2011, 39(Database issue):D561-568.

51. von Mering C, Jensen LJ, Snel B, Hooper SD, Krupp M, Foglierini M, Jouffre $\mathrm{N}$, Huynen MA, Bork P: STRING: known and predicted protein-protein associations, integrated and transferred across organisms. Nucleic Acids Res 2005, 33:D433-D437.

52. Dennis G, Sherman BT, Hosack DA, Yang J, Gao W, Lane HC, Lempicki RA: DAVID: Database for annotation, visualization, and integrated discovery. Genome Biol 2003, 4(5):P3.

53. Kanehisa M, Goto S, Furumichi M, Tanabe M, Hirakawa M: KEGG for representation and analysis of molecular networks involving diseases and drugs. Nucleic Acids Res 2010, 38(Database issue):D355-360.

54. D'Eustachio P: Reactome knowledgebase of human biological pathways and processes. Methods Mol Biol 2011, 694:49-61.

55. Cline MS, Smoot M, Cerami E, Kuchinsky A, Landys N, Workman C, Christmas R, Avila-Campilo I, Creech M, Gross B, et al: Integration of biological networks and gene expression data using Cytoscape. Nat Protoc 2007, 2(10):2366-2382

56. Wang $X$ : miRDB: a microRNA target prediction and functional annotation database with a wiki interface. RNA 2008, 14(6):1012-1017.

57. Watanabe T, Watanabe S, Kawaoka Y: Cellular networks involved in the influenza virus life cycle. Cell Host Microbe 2010, 7(6):427-439.

58. Nathans R, Chu CY, Serquina AK, Lu CC, Cao H, Rana TM: Cellular MicroRNA and P bodies modulate host-HIV-1 interactions. Mol Cell 2009, 34(6):696-709

59. Lecellier $\mathrm{CH}$, Dunoyer $\mathrm{P}$, Arar K, Lehmann-Che J, Eyquem S, Himber C, Saib A, Voinnet O: A cellular microRNA mediates antiviral defense in human cells. Science 2005, 308(5721):557-560.

60. Jopling $C L$, Schuetz S, Sarnow P: Position-dependent function for a tandem microRNA miR-122-binding site located in the hepatitis $C$ virus RNA genome. Cell Host Microbe 2008, 4(1):77-85.

61. Jangra RK, Yi M, Lemon SM: Regulation of hepatitis $C$ virus translation and infectious virus production by the MicroRNA miR-122. J Virol 2010, 84(13):6615-6625.

62. Chang JH, Cruo JT, Jiang D, Guo HT, Taylor JM, Block TM: Liver-specific MicroRNA miR-122 enhances the replication of hepatitis $C$ virus in nonhepatic cells. J Virol 2008, 82(16):8215-8223.

63. Steiner DF, Thomas MF, Hu JK, Yang Z, Babiarz JE, Allen CDC, Matloubian M, Blelloch $\mathrm{R}$, Ansel KM: MicroRNA-29 regulates T-Box transcription factors and interferon-gamma production in helper T cells. Immunity 2011, 35(2):169-181

64. Ding Z, Wang $X$, Khaidakov M, Liu S, Mehta JL: MicroRNA hsa-let-7g targets lectin-like oxidized low-density lipoprotein receptor-1 expression and inhibits apoptosis in human smooth muscle cells. Exp Biol Med 2012, 237(9):1093-1100. 
65. Kumar M, Ahmad T, Sharma A, Mabalirajan U, Kulshreshtha A, Agrawal A, Ghosh B: Let-7 microRNA-mediated regulation of IL-13 and allergic airway inflammation. J Allergy Clin Immunol 2011, 128(5):1077-1085.

66. Zhu Z, Homer RJ, Wang Z, Chen Q, Geba GP, Wang J, Zhang Y, Elias JA: Pulmonary expression of interleukin-13 causes inflammation, mucus hypersecretion, subepithelial fibrosis, physiologic abnormalities, and eotaxin production. J Clin Invest 1999, 103(6):779-788.

67. Fezeu L, Julia C, Henegar A, Bitu J, Hu FB, Grobbee DE, Kengne AP, Hercberg S, Czernichow S: Obesity is associated with higher risk of intensive care unit admission and death in influenza A (H1N1) patients: a systematic review and meta-analysis. Obes Rev 2011, 12(8):653-659.

68. Louie JK, Acosta M, Samuel MC, Schechter R, Vugia DJ, Harriman K, Matyas BT, Calif Pandem HNWG: A novel risk factor for a novel virus: obesity and 2009 pandemic influenza a (H1N1). Clin Infect Diseases 2011, 52(3):301-312

69. Jain S, Chaves SS: Obesity and influenza. Clin Infect Diseases 2011 53(5):422-424

70. Kornum JB, Norgaard M, Dethlefsen C, Due KM, Thomsen RW, Tjonneland A, Sorensen HT, Overvad K: Obesity and risk of subsequent hospitalisation with pneumonia. Eur Res J 2010, 36(6):1330-1336.

71. Hingston CD, Holmes TW, Saayman AG, Wise MP: Obesity and risk of pneumonia in patients with influenza. Eur Res J 2011, 37(5):1299-1299.

72. Kok J, Blyth CC, Foo H, Bailey MJ, Pilcher DV, Webb SA, Seppelt IM, Dwyer $D E$, Iredell JR: Viral pneumonitis is increased in obese patients during the first wave of pandemic a(H1N1) 2009 virus. PLoS One 2013, 8(2):e55631.

73. Smith AG, Sheridan PA, Tseng RJ, Sheridan JF, Beck MA: Selective impairment in dendritic cell function and altered antigen-specific CD8(+) T-cell responses in diet-induced obese mice infected with influenza virus. Immunology 2009, 126(2):268-279.

74. Smith AG, Sheridan PA, Harp JB, Beck MA: Diet-induced obese mice have increased mortality and altered immune responses when infected with influenza virus. J Nutr 2007, 137(5):1236-1243.

75. Karlsson EA, Sheridan PA, Beck MA: Diet-induced obesity impairs the T cell memory response to influenza virus infection. J Immunol 2010, 184(6):3127-3133.

76. Hulsmans M, Van Dooren E, Mathieu C, Holvoet P: Decrease of miR-146b$5 p$ in monocytes during obesity is associated with loss of the antiinflammatory but not insulin signaling action of adiponectin. PLOS One 2012, 7(2):e32794.

77. Yan X, Huang Y, Zhao JX, Rogers CJ, Zhu MJ, Ford SP, Nathanielsz PW, Du $M$ : Maternal obesity downregulates microRNA let-7g expression, a possible mechanism for enhanced adipogenesis during ovine fetal skeletal muscle development. Int J Obes 2013, 37(4):568-575.

78. Schmidt WM, Spiel AO, Jilma B, Wolzt M, Wuller M: In vivo profile of the human leukocyte microRNA response to endotoxemia. Biochem Biophysic Res Comm 2009, 380(3):437-441.

79. Giamarellos-Bourboulis EJ, Raftogiannis M, Antonopoulou A, Baziaka F, Koutoukas P, Savva A, Kanni T, Georgitsi M, Pistiki A, Tsaganos T, et al: Effect of the Novel Influenza A (H1N1) Virus in the Human Immune System. PloS One 2009, 4(12):e8393.

80. Palacios G, Hornig M, Cisterna D, Savji N, Bussetti AV, Kapoor V, Hui J, Tokarz $R$, Briese T, Baumeister $E$, et al: Streptococcus pneumoniae coinfection is correlated with the severity of H1N1 pandemic influenza. PLOS One 2009, 4(12):e8540.

81. Cuadrado A, Nebreda AR: Mechanisms and functions of p38 MAPK signalling. Biochem J 2010, 429:403-417.

82. Xing Z, Cardona CJ, Anunciacion J, Adams S, Dao N: Roles of the ERK MAPK in the regulation of proinflammatory and apoptotic responses in chicken macrophages infected with H9N2 avian influenza virus. J Gen Virol 2010, 91:343-351.

83. Marchant D, Singhera GK, Utokaparch S, Hackett TL, Boyd JH, Luo ZS, Si XN, Dorscheid DR, McManus BM, Hegele RG: Toll-like receptor 4-mediated activation of p38 mitogen-activated protein kinase is a determinant of respiratory virus entry and tropism. J Virol 2010, 84(21):11359-11373.

84. Eierhoff T, Hrincius ER, Rescher U, Ludwig S, Ehrhardt C: The epidermal growth factor receptor (EGFR) promotes uptake of influenza a viruses (IAV) into host cells. PLoS Pathog 2010, 6(9):e1001099.

85. Wurzer WJ, Planz O, Ehrhardt C, Giner M, Silberzahn T, Pleschka S, Ludwig S: Caspase 3 activation is essential for efficient influenza virus propagation. EMBO J 2003, 22(11):2717-2728
86. SchultzCherry S, Hinshaw VS: Influenza virus neuraminidase activates latent transforming growth factor beta. J Virol 1996, 70(12):8624-8629.

87. Bloomston M, Frankel WL, Petrocca F, Volinia S, Alder H, Hagan JP, Liu CG, Bhatt D, Taccioli C, Croce CM: MicroRNA expression patterns to differentiate pancreatic adenocarcinoma from normal pancreas and chronic pancreatitis. JAMA 2007, 297(17):1901-1908.

88. Lehmann U, Hasemeier B, Romermann D, Muller M, Langer F, Kreipe H: Epigenetic inactivation of microRNA genes in mammary carcinoma. Verh Dtsch Ges Pathol 2007, 91:214-220.

89. Tan Z, Randall G, Fan J, Camoretti-Mercado B, Brockman-Schneider R, Pan L, Solway J, Gern JE, Lemanske RF, Nicolae D, et al: Allele-specific targeting of microRNAs to HLA-G and risk of asthma. Am J Human Gen 2007, 81(4):829-834

90. Pan W, Zhu S, Yuan M, Cui HJ, Wang LJ, Luo XB, Li J, Zhou HB, Tang YJ, Shen N: MicroRNA-21 and MicroRNA-148a contribute to DNA hypomethylation in lupus CD4(+) T cells by directly and indirectly targeting DNA methyltransferase 1. J Immunol 2010, 184(12):6773-6781.

91. Liu X, Zhan Z, Xu L, Ma F, Li D, Guo Z, Li N, Cao X: MicroRNA-148/152 impair innate response and antigen presentation of TLR-triggered dendritic cells by targeting CaMKII alpha. J Immunol 2010, 185(12):7244-7251.

92. Rouas R, Fawad-Kazan $H$, El Zein N, Lewalle P, Rothe F, Simion A, Akl H, Mourtada M, El Rifai M, Burny A, et al: Human natural Treg microRNA signature: Role of microRNA-31 and microRNA-21 in FOXP3 expression. Eur J Immunol 2009, 39(6):1608-1618.

93. Wieckiewicz J, Goto R, Wood KJ: T regulatory cells and the control of alloimmunity: from characterisation to clinical application. Curr Opinion Immunol 2010, 22(5):662-668.

94. Chen HX, Chen BG, Shi WW, Zhen R, Xu DP, Lin AF, Yan WH: Induction of cell surface human leukocyte antigen-G expression in pandemic H1N1 2009 and seasonal H1N1 influenza virus-infected patients. Human Immunol 2011, 72(2):159-165.

95. Pavlovic J, Haller O, Staeheli P: Human and mouse Mx-proteins inhibit different steps of the influenza-virus multiplication cycle. J Virol 1992, 66(4):2564-2569.

96. Haller O, Staeheli P, Kochs G: Interferon-induced Mx proteins in antiviral host defense. Biochimie 2007, 89(6-7):812-818.

97. Tumpey TM, Szretter KJ, Van Hoeven N, Katz JM, Kochs G, Haller O, GarciaSastre A, Staeheli $P$ : The $M \times 1$ gene protects mice against the pandemic 1918 and highly lethal human H5N1 influenza viruses. J Virol 2007, 81(19):10818-10821.

98. Cilloniz C, Pantin-Jackwood MJ, Ni C, Carter VS, Korth MJ, Swayne DE, Tumpey TM, Katze MG: Molecular signatures associated with Mx1mediated resistance to highly pathogenic influenza virus infection: mechanisms of survival. J Virol 2012, 86(5):2437-2446.

doi:10.1186/1471-2334-13-257

Cite this article as: Song et al.: Microarray analysis of MicroRNA expression in peripheral blood mononuclear cells of critically ill patients with influenza A (H1N1). BMC Infectious Diseases 2013 13:257.

\section{Submit your next manuscript to BioMed Central and take full advantage of:}

- Convenient online submission

- Thorough peer review

- No space constraints or color figure charges

- Immediate publication on acceptance

- Inclusion in PubMed, CAS, Scopus and Google Scholar

- Research which is freely available for redistribution 